\title{
AKTIVITAS ANTIOKSIDAN EKSTRAK ETANOL BIJI PINANG (Areca catechu, L)
}

\section{ANTIOXIDANT ACTIVITY OF Areca catechu ETHANOLIC EXTRACT}

\author{
Heru A. Cahyanto \\ Balai Riset dan Standardisasi Industri Pontianak \\ Email : heru-a@kemenperin.go.id
}

Received : 07/08/2018; revised : 14/12/2018; accepted : 18/12/2018

Published online : 31/12/2018

\begin{abstract}
ABSTRAK
Biji pinang mengandung senyawa antioksidan yang dapat menghambat radikal bebas seperti senyawa tannin dan flavonoid. Tujuan penelitian ini adalah untuk mengetahui aktivitas antioksidan ekstrak etanol biji pinang dengan metode DPPH dan menetapkan kadar kandungan senyawa tannin dan flavonoid. Biji pinang diekstraksi secara maserasi menggunakan ethanol 95\% dan dipekatkan sampai terbentuk ekstrak kental dengan rendemen 21,6\%. Ekstrak yang diperoleh distandardisasi dan dilakukan uji aktivitas antioksidan dengan metode DPPH. Ekstrak etanol biji pinang mengandung senyawa flavonoid dan tannin dengan kadar masing-masing 3,7\% dan $8,53 \%$. Hasil uji menunjukkan ekstrak biji pinang memenuhi persyaratan standar bahan ekstrak serta memiliki aktivitas antioksidan sebesar $3,5 \mu \mathrm{g} / \mathrm{ml}$.
\end{abstract}

Kata kunci : antioksidan, biji pinang, ekstrak

\begin{abstract}
Areca nuts contain antioxidants compounds that can inhibit free radicals such tannins and flavonoids. The aimed of this study was to determine the antioxidant activity of areca nut extract with DPPH method and the content of tannin and flavonoid compounds. Areca nut extracted by maceration using 95\% ethanol and concentrated until viscous extract formed with a yield of $21,6 \%$. The extract was standardized and the antioxidant activity testedusing DPPH method. Ethanolic extract of areca nuts contains flavonoids and tannins 3,7\% and 8,53\% respectively. The results, areca nuts extract met the standard requirements of the extract material and has antioxidant activity i.e $3,5 \mu \mathrm{g} / \mathrm{ml}$.
\end{abstract}

Keywords : antioxidan, areca nuts, extract

\section{PENDAHULUAN}

Pinang dengan nama latinnya Areca catechu, L merupakan salah satu tanaman family palmae selain pohon kelapa yang mudah tumbuh dan berkembang biak melalui biji, dan dari bijinya itu dapat dimanfaatkan sebagai bahan baku makanan, minuman, obat, pewarna dan kosmetik.

Proses pengolahan biji pinang masih dilakukan secara sederhana, yaitu dalam keadaan kering utuh atau telah dibelah dan dengan kualitas yang masih rendah. Biji pinang yang diolah masyarakat diekspor ke negara seperti Pakistan, Thailand, India, Vietnam, Bangladesh dimana negara ini biji pinang diolah menjadi makanan seperti permen dan kosmetik.

Produksi atau ekspor biji pinang di Indonesia selalu meningkat dari tahun ke tahun. Kementerian Perdagangan berdasar BPS menyebutkan dalam kurun waktu tahun 2012 sampai 2015 terjadi peningkatan jumlah ekspor dari 42 ribu ton menjadi 47,1 ribu ton. Ekspor pinang di dunia dilakukan oleh beberapa negara termasuk Indonsia dengan persentase seperti Tabel 1

Secara tradisional, di Indonesia biji pinang dimanfaatkan sebagai bahan makanan seperti apam, minuman seperti jus, bahan lulur tradisional dan obat diare serta cacingan. Biji pinang atau lebih dikenal dengan betel nuts atau areca nuts mengandung senyawa alkaloid seperti arecoline, arecaine, arecolidine, guvacine, iso-guvacine, guvacoline dan choline serta tannin (Muir and Kirk, 1960). Tannin merupakan salah satu senyawa polifenol berperan dalam mengencangkan gusi dan menghentikan pendarahan (Satriani, 2017).

Tabel 1. Data negara pengekspor pinang

\begin{tabular}{clc}
\hline No & \multicolumn{1}{c}{ Negara } & Share (\%) \\
\hline 1 & Amerika Serikat & 34,51 \\
2 & China dan Hongkong & 23,38 \\
3 & German & 5,73 \\
29 & Indonesia & 0,17 \\
\hline
\end{tabular}


Salah satu aktivitas senyawa fenol adalah sebagai antioksidan, yang dapat menangkap radikal bebas. Penelitian ini dilakukan untuk mengetahui aktivitas ekstrak etanol biji pinang yang diekstrak secara maserasi menggunakan etanol $95 \%$. Data aktivitas antioksidan ekstrak ini dapat digunakan untuk mendukung pengembangan bahan baku yang berasal dari herbal baik untuk industri obat maupun kosmetik, sehingga biji pinang tidak hanya dijual dalam bentuk simplisia kering.

\section{METODE PENELITIAN}

\section{Bahan dan alat}

Bahan yang digunakan adalah biji pinang dari Kota Pontianak, etanol 95\%, 1,1-diphenil-2picrylhydrazyl (DPPH). Alat yang digunakan adalah rotary evaporator, oven, blender, ayakan, alat-alat maserasi.

\section{Metode}

Ekstraksi menggunakan penyari etanol 95\% 10x bagian berat serbuk biji pinang yaitu $1 \mathrm{~kg}$ (serbuk). Maserasi selama 3 hari disertai pengadukan. Filtrat yang diperoleh diuapkan dalam rotary evaporator, dan diatas waterbath sampai didapatkan ekstrak kental.

Metode uji aktivitas antioksidan menggunakan campuran larutan DPPH dan sampel dalam seri konsentrasi. Campuran larutan dihomogenkan dan diinkubasi 30 menit sebelum diukur menggunakan Spektrofotometer UV-Vis pada panjang gelombang $517 \mathrm{~nm}$. Aktivitas antioksidan sampel dihitung dari nilai hambatan serapan larutan DPPH sebagai persentasi inhibisi :

$$
\% \text { Inhibisi }=\left(\frac{A_{k}-A_{s}}{A_{k}}\right) \times 100
$$

dan dari hubungan konsentrasi dan \% inhibisi dibuat persamaan regresi untuk menentukan nilai $I C_{50}$. Persamaan regresi linear $\mathrm{y}=\mathrm{ax}+\mathrm{b}$ dimana:

$$
\begin{aligned}
& y=\% \text { inhibisi } \\
& x=\text { konsentrasi }
\end{aligned}
$$

\section{HASIL DAN PEMBAHASAN}

\section{Standardisasi Ekstrak Biji Pinang}

Ekstrak kental etanol biji pinang yang diperoleh rendemen sebesar 21,6\% memiliki konsistensi kental, warna coklat dan bau khas buah pinang. Standardisasi ekstrak etanol menurut parameter standar umum ekstrak dilakukan berupa parameter nonspesifik dan parameter spesifik. Standardisasi ini untuk menjamin kontinuitas mutu ekstrak yang dihasilkan (Depkes RI, 2000). Parameter nonspesifik meliputi kadar air 23,7\% kadar abu 0,79\% dan kadar abu tak larut asam 0,005\%.
Parameter diatas telah memenuhi persyaratan nonspesifik dalam Farmakope Herbal.

\section{Kadar Tannin dan Flavonoid}

Parameter spesifik berupa penentuan metabolit sekunder berupa secara kualitatif dan kuantitatif ekstrak biji pinang mengandung senyawa flavonoid dan tanin dengan kadar masing-masing $3,7 \%$ dan $8,53 \%$. Senyawa tannin dan flavonoid merupakan senyawa metabolit sekunder yang paling banyak terdapat dalam tumbuhan. Senyawa tanin lebih banyak kadarnya daripada flavonoid memgingat pelarut yang digunakan adalah etanol $95 \%$ yang relatif kepolarannya, sementara flavonoid lebih banyak larut dalam etanol yang lebih polar seperti etanol $70 \%$. Selain senyawa tersebut dalam biji pinang juga terkandung karbohidrat, lemak, serat, alkaloid dan mineral (Jaiswal et al., 2011 dalam Revina et al., 2017).

\section{Aktivitas Antioksidan}

Aktivitas antioksidan flavonoid adalah kemampuannya dalam melepas proton (Prabawati, 2016) sehingga dapat menangkap radikal bebas juga berperan dalam mengikat logam (chelating agent) (Borsari et al, 2001). Tannin merupakan senyawa polifenol yang lebih kompleks. Tannin memiliki aktivias yang banyak antara lain anti tumor (Yoshizawa, 1987), anti virus (Nonaka et al., 1990), antibakteri (Pambayun et al., 2007), dapat meningkatkan respon imun (Dewi, 2012), anti hipertensi/diuretik (Carolia, 2016). Aktivitas antioksidan tannin akibat adanya gugus siklik dan kemampuannya sebagai donor proton seperti flavonoid. Juga dalam pembentukan kompleks dengan logam (Nathan, 2009).

\section{Uji Antioksidan}

Antioksidan adalah senyawa yang dapat menangkap atau meredam oksidan dalam tubuh. Mekanisme kerjanya melalui donor satu elektron, sehingga senyawa oksidan atau radikal bebas aktivitasnya terhambat. Radikal bebas sendiri suatu molekul yang memiliki elektron tidak berpasangan, sehingga sangat reaktif. $I_{50}$ merupakan konsentrasi antioksidan dimana dapat menghambat $50 \%$ radikal bebas. Uji aktivitas antioksidan menggunakan metode DPPH (1,1-diphenil-2-picrylhydrazyl). Senyawa ini merupakan radikal bebas yang akan memudar warnanya bila berinteraksi dengan senyawa yang dapat menetralkannya. Digunakan metode ini juga karena senyawa yang diuji berupa senyawa polar berupa ekstrak etanol, dimana kristal DPPH larut dan memberikan absorbansi maksimum dengan pelarut etanol. Kontrol berupa absorbansi serapan senyawa DPPH sebelum ditambahkan senyawa uji yaitu 0,747 . 
Tabel 2. Pengukuran Nilai \% Inhibisi

\begin{tabular}{cccccccc}
\hline \multirow{2}{*}{ Konsentrasi } & Abs & Abs & Abs & \multicolumn{2}{c}{ \% Penangkapan radikal bebas (\%) } & \multirow{2}{*}{ Rata-rata } \\
& I & II & III & I & II & III & \\
Kontrol & & 0,747 & & & & & \\
1.04 & 0.597 & 0.600 & 0.601 & 20.08 & 19.68 & 19.54 & 19.77 \\
2.09 & 0.504 & 0.504 & 0.507 & 32.53 & 32.40 & 32.13 & 32.35 \\
3.13 & 0.405 & 0.407 & 0.409 & 45.78 & 45.25 & 45.25 & 45.52 \\
4.18 & 0.310 & 0.312 & 0.314 & 58.50 & 58.23 & 57.97 & 58.23 \\
5.22 & 0.208 & 0.211 & 0.215 & 72.16 & 71.75 & 71.22 & 71.71 \\
\hline
\end{tabular}

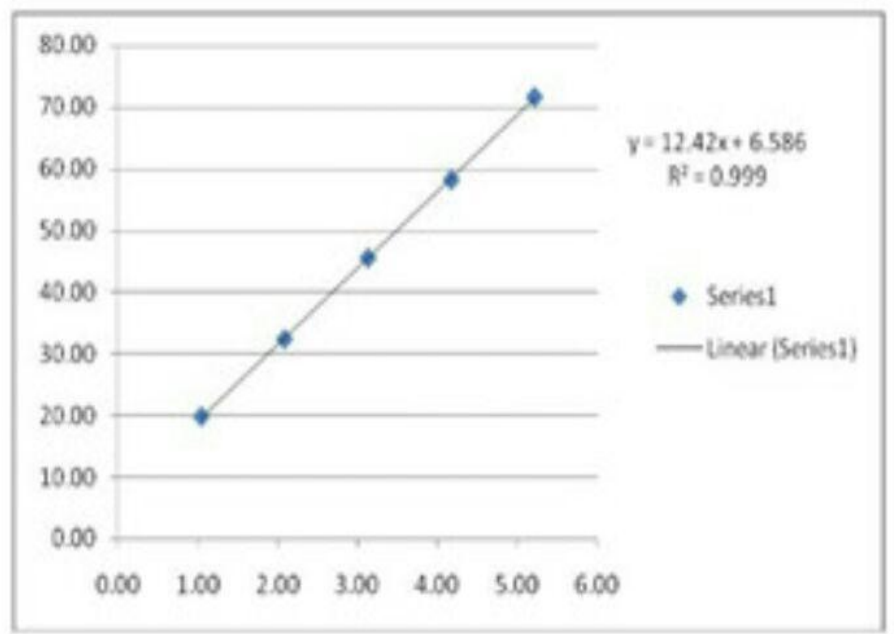

Gambar 1. Grafik Regresi Linear Konsentrasi dan \% Inhibisi

Persen inhibisi diperoleh dari selisih absorbansi kontrol $\left(A_{k}\right)$ dan sampel $\left(A_{s}\right)$ dibagi absorbansi kontrol $\left(A_{k}\right)$ dikalikan 100 . Hasil uji dan nilai \% inhibisi seperti terlihat pada Tabel 2.

Dari hasil pengukuran diperoleh rata-rata penangkapan radikal bebas, dan dibuat persamaan umum regresi linear seperti gb1. Persamaan regresi ini digunakan untuk menentukan nilai $I C_{50}$. Nilai $I C_{50}$ didapatkan dari perhitungan adalah $3,5 \mu \mathrm{g} / \mathrm{ml}$. Nilai aktivitas antioksidan diatas, $3,5 \mu \mathrm{g} / \mathrm{ml}$ termasuk dalam aktivitas kuat (Blouis, 1958). Semakin besar nilai $I C_{50}$, semakin kecil nilai aktivitas antioksidannya.

\section{KESIMPULAN}

Ekstrak biji pinang hasil ekstraksi menggunakan etanol $95 \%$ memiliki rendemen $21,6 \%$, konsistensi kental, warna coklat dan bau khas dengan kadar air 23,7\%, kadar abu 0,795 dan kadar abu tak larut asam 0,005\% serta memiliki aktivitas antioksidan $3.5 \mu \mathrm{g} / \mathrm{ml}$, masuk kategori kuat.

\section{DAFTAR PUSTAKA}

Blouis, M.S. 1958. Antioxidant Determinations By The Use of a Stable Free Radical. Nature 1199-1200

Borsari, M., Gabbi, C., Ghelfi, F., Grandi, R., Saladini, M., Severi, S., Borella, F. 2001.
Silybin, A New Iron-Chelating Agent, Journal of Inorganic Biochemistry 85(2-3): 123-129, Elsevier.

Carolia, N., Noventi, W. 2016. Potensi Ekstrak Daun Sirih Hijau (Piper battle, L) Sebagai Alternatif Terapi Acne Vulgaris. Majority 5(1):140-145

Departemen Kesehatan RI. 2000. Parameter Standar Umum Ekstrak Tumbuhan Obat, Direktorat Jenderal Pengawasan Obat dan Makanan, Jakarta

Departemen Kesehatan RI. 2009. Farmakope Herbal Indonesia (FHI) Edisi I, Jakarta

Dewi M.M. 2012. Formulasi SediaanTablet Hisap Katekin Gambir(Uncaria gambir Roxb) Sebagai Imunomodulator Dengan Metode Granulasi Basah. Skripsi FKIK UIN Syarif Hidayatullah. Jakarta.

Harrizul Rivai, Lisa Putriani, Mahyuddin. 2010. Karakterisasi Flavonoid Antioksidan Dari daun Jambu Biji (Psidium guajava L). Jurnal Farmasi Higea 2(2): 127-136

Kemendag. 2017. Peluang Ekspor Gambir dan Biji Pinang. Warta Ekspor. Jakarta

Muir CS, Kirk R. Betel. 1960. Tobacco, and Cancer of The Mouth, British Journal of Cancer14(4): 597-608

Nathan R. Perron, Julia L. Brumaghim. 2009. A Review of The Antioxidant Mechanisms of Polyphenol Compound Related to Iron 
Binding. Cell Biochemistry and Biophysics 53(2): 75

Nonaka G, Nishioka I, Nishizawa M, Yamagishi T, Kashiwada Y, Dutschman G.E, Bodner A.J, Kilkuskie R.E, Cheng Y, and Lee K. 1990. Journal of Natural Products53 (3) : 587-595

Prabawati, S.Y., Wijayanto, A. 2016. Sintesis Senyawa 1,4 -Bis[(1-Hidroksi-4-T-ButylPhenyl) Methyl] Piperazine Sebagai Zat Antioksidan. Molekul 11(2) : 220-229.

Revina Petrina, Andi Hairil Alimuddin dan Harlia, 2017. Uji Aktivitas Antioksidan dan Toksisitas Kulit Biji Pinang Sirih (Areca catechu L). Jurnal Kimia Khatulistiwa, Vol 6(2): 70-77.

Satriani Lamma. 2017. Analisis Kadar Tannin Total dari Alga Coklat (Sargassum sp dan Padina sp) sebagai Obat Anti Pendarahan. Skripsi FKG. Makasar.

Yoshizawa S, Horiuchi T, Fujiki H, Yoshida T, Okuda T, Sugimura T, 1987. Antitumor Promoting Activity of (-) Epigallocatechin Gallate, The Main Constituent of Tannin In Green Tea. Phytotherapy Research 1(1): 44-47 